\title{
A local child psychiatric service as viewed by district social workers
}

\author{
S. J. Dover
}

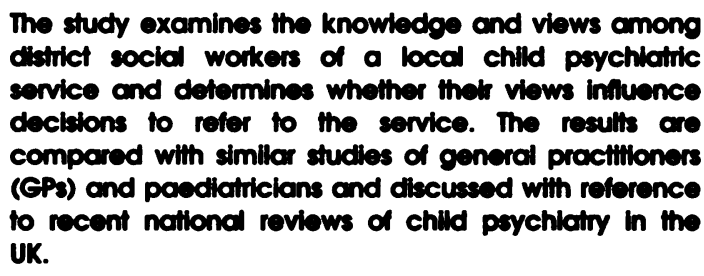

The recent NHS Health Advisory Service review of child and adolescent mental health services (1995) identified a need for secondary child and adolescent psychiatric services to be responsive to the views of primary care commissioners in service development. The report also highlighted the need for primary care agencies to have a good knowledge of existing local secondary services to use in the commissioning process.

There have been several studies relating to the views and knowledge of child psychiatric services among general practitioners (GPs) (Markantonakis \& Mathai, 1990; Thompson \& Place, 1995) and paediatricians (Oke \& Mayer, 1991; Church et al, 1993). There have, however, been no similar studies of district social workers. Such data is important as social workers regularly refer cases to child psychiatric services and potentially have contact with large numbers of children at risk of psychiatric disorder.

The aims of this study were: to assess the knowledge and views among district social workers of a local community-based child and adolescent service; and to determine whether these views might influence decisions to make referrals to the service.

\section{The study}

A questionnaire was sent to all group managers, team managers and senior social work practitioners working in district-based child and family social work teams in North Staffordshire. Social workers were based in purchaser and provider units. The questionnaire had four main sections designed to assess: (1) the knowledge of existing psychiatric services for children and adolescents in North Staffordshire; (2) the opinion of local child psychiatric services based on personal experience of referral to the service, including views on accessibility, communication, outcome of referral and views on how the service might be improved; (3) the views of what was most wanted from an ideal child psychiatric service; and (4) the factors that might influence decisions to make future referrals to the service.

The child and adolescent psychiatric service in North Staffordshire is community-based and serves a largely urban population of 500000 . Referrals are taken from a wide range of agencies, including GPs, paediatricians, education services and district child and family social work teams. The service offers a variety of models of assessment and treatment, including an adolescent in-patient unit, for individual referrals as appropriate.

\section{Findings}

Fifty-three questionnaires were sent out of which 43 were returned ( $81 \%$ response rate). Thirtythree of these social workers had made referrals to the service in the last two years.

\section{Awareness of the service}

Table 1 shows awareness of local psychiatric services among social workers. Out of a total of 11 therapeutic services available locally, only $5 \%$ of the sample were aware of the existence of all of these: $30 \%$ were aware of less than half of the services. The mean response was for awareness of 6.6 services.

\section{Opinions of the local service}

Accessibility. Social workers were critical of the accessibility of the service: $97 \%$ of the sample wanted all children referred to be seen within 
Table 1. Awareness of local services among social workers

\begin{tabular}{|c|c|}
\hline Service avallable & $\begin{array}{l}\text { Number of social } \\
\text { workers onwore of } \\
\text { service }(n-43)\end{array}$ \\
\hline $\begin{array}{l}\text { Assessment by psychiatist } \\
\text { Assessment by multidisciplinary } \\
\text { team }\end{array}$ & $\begin{array}{l}41(95 \%) \\
17(39 \%)\end{array}$ \\
\hline $\begin{array}{l}\text { Informal consultation service } \\
\text { Family therapy } \\
\text { Indlidual psychotherapy for } \\
\text { children }\end{array}$ & $\begin{array}{l}27(63 \%) \\
35(81 \%) \\
31(72 \%)\end{array}$ \\
\hline $\begin{array}{l}\text { Indlvidual psychotherapy } \\
\text { for adolescents }\end{array}$ & $33(77 \%)$ \\
\hline $\begin{array}{l}\text { Supportive counselling for parents } \\
\text { Group therapy for sexually- } \\
\text { abused teenage girls }\end{array}$ & $\begin{array}{l}10(23 \%) \\
29(67 \%)\end{array}$ \\
\hline $\begin{array}{l}\text { Medication for children } \\
\text { Medication for adolescents } \\
\text { in-pattient adolescent unit }\end{array}$ & $\begin{array}{l}15(35 \%) \\
19(44 \%) \\
36(84 \%)\end{array}$ \\
\hline
\end{tabular}

one month (only $12 \%$ of referrals had been seen within this time and 35\% had waited longer than three months); $82 \%$ of social workers stated that it was either difficult or very difficult to get a child seen by the service. The most common reasons for this were: long waiting lists; narrow criteria to accept a referral; refusal to see child unless in a settled environment; lack of clear referral criteria.

Communication. Forty-nine per cent of the sample stated communication with the service had been good, but $46 \%$ described it as poor and $5 \%$ very poor. Among those who responded negatively. $26 \%$ suggested this was largely due to lack of personal contact between the services. Social workers were also unhappy with the delay in receiving feedback about cases. Suggestions by social workers as to how to improve communications included: (1) joint case planning meetings for individual referrals (59\%); (2) for the service to identify a 'link-person' to liaise about individual cases (32\%); (3) for the service to have regular open days and newsletters about service provision (23\%); and (4) for the service to define its role more precisely (18\%).

Awareness of the informal consultation service among social workers was not significantly associated with better views of communication.

Overall views of the service. Social workers were negative in their overall views of the service: $63 \%$ described it as poor or very poor, $37 \%$ described it as good. Reasons stated for dissatisfaction with the service included problems with accessibility to the service (74\%) and poor communication between services (69\%), both of which have been discussed in detail above. Other reasons included lack of understanding of role of district social worker by the service (24\%), lack of shared responsibility for cases by working with district social worker (21\%) and cases discharged too easily for poor cooperation with treatment (18\%).

Aspects of the service recetved favourably by social workers included: discussion with clinic staff prior to making a referral (32\%); service good when accessed (23\%). Overall views of the service were not significantly associated with level of knowledge of the service nor with views on accessibility or communication.

Referral outcome. Forty-five per cent of social workers felt that their client had been helped by referral to the service, $42 \%$ stated that the client had not been helped, and $13 \%$ of social workers did not comment.

There were no significant associations between opinions of referral outcome and views of accessibility and communication or level of knowledge about the service.

What social workers want from an ideal service Fifty-one per cent of social workers wanted a service which was able to respond quickly and easily to referral requests. In particular. $20 \%$ of the sample wanted a service with clearly defined referral criteria, 20\% suggested that services should involve district social workers directly in both the planning and provision of treatment packages, with a further $28 \%$ specifically wanting a formalised consultation service.

Social workers also suggested that the current local service would be improved by: decreasing waiting lists (24\%); increased integration with district social services teams (14\%); and more staff available to deal with referrals (36\%).

Table 2. Factors influencing social workers' decisions not to refer to the service

\begin{tabular}{|c|c|}
\hline $\begin{array}{l}\text { Foctors influencing decibion not } \\
\text { to refer }\end{array}$ & $\begin{array}{l}\text { Number of socid } \\
\text { workers influenced } \\
\text { by this foctor } \\
\text { (n=43) }\end{array}$ \\
\hline $\begin{array}{l}\text { Referral unacceptable to family } \\
\text { Stigmatisation of child if referred } \\
\text { to service }\end{array}$ & $\begin{array}{l}34(79 \%) \\
14(33 \%)\end{array}$ \\
\hline $\begin{array}{l}\text { Fear of flooding service if refer } \\
\text { too many cases }\end{array}$ & 11 (25\%) \\
\hline $\begin{array}{l}\text { Referral does not achieve much } \\
\text { Poor previous experience of service }\end{array}$ & $\begin{array}{l}29(68 \%) \\
25(59 \%)\end{array}$ \\
\hline
\end{tabular}


Factors influencing decisions to make future referrals to the service

Table 2 shows factors which might influence a social worker in deciding not to refer to the service in future.

Social workers with negative overall views of the service were significantly more likely to cite poor previous experience of the service as a reason not to refer to the service again than social workers with posittve overall views $(P \leqslant 0.0001)$. There was no association between experiences of previous client outcome and decisions to refer on basis of views of what referral might achieve $(P=0.81)$.

\section{Comments}

The response rate to the questionnaire was good and a high proportion $(77 \%)$ of responders had practical experience of making referrals to the service. The views of a full range of district-based social services units were obtained.

The results of satisfaction surveys must be viewed with caution, particularly where they are used to obtain qualitative information about health care provision (Learmonth et al, 1990). While this survey does serve to highlight both individual and general areas of concern among social workers and in addition has generated supportive qualitative data, the results should therefore be viewed with caution. In particular, data relating to perceived effectiveness of the service is subjective and needs to be considered in association with other experiences of service utllisation. Nevertheless, these results do highlight areas of concern.

There is a poor level of understanding among district social workers in North Staffordshire about the types of child psychiatric interventions available locally. The reasons for this are unclear but social workers have identified a need for the child psychiatric service to define its role more clearly. Previous studies have shown that there is also a poor level of understanding about child psychiatric services among GPs (Markantonakds \& Matai, 1990: Thompson \& Place, 1995) and paediatricians (Oke \& Mayer, 1991). This would seem to indicate that the problem is a general one and not confined to social workers.

District social workers are critical in their overall views of child psychiatric services in North Staffordshire, with particular areas of concern being poor accessibility due to long waiting lists and problems in communication. Social workers recognise that there is a need for improved cooperation between the two services, particularly at an individual case level. Studies of GPs (Thompson \& Place, 1995) and paediatricians (Oke \& Mayer, 1991) have highlighted similar areas of concern, which would again suggest that these are general problems for all referrers.
Despite criticisms of the service, nearly half of the social workers felt that their client had been helped by referral. This is despite the fact that a previous study of the same service revealed that the largest group of referrals is for conduct disorder (Dover et al, 1994), a condition whose outcome may be poor even after therapeutic intervention.

Finally, individual social workers' vlews of the service seem to be important influences on decisions whether to refer to the service. Social workers with negative views of the service are likely to consider poor previous experiences of the service in decisions whether to refer again.

To conclude, many of the criticisms of local services revealed in this study have been highlighted as problems throughout the UK in reviews of national child psychiatric services. Both the NHS Health Advisory Service Report Together We Stand (1995) and the Kurtz Report Services for the Mental Health of Children and Young People in England - A National Review (Kurtz et al, 1994) were critical of existing services. These results support their conclusions that child psychiatric services need to be more accessible to primary care agencies, including Social Services, and that communication and understanding between primary and secondary services needs to be improved. These recommendations must, however, be viewed against the background of increasing demands on under-resourced child and adolescent psychiatric services. Many districts are unable to meet these demands and waiting times of three or even six months are common. As a result of these difficulties, there is a tendency for services to be forced to focus on crisis intervention rather than prevention or support of primary care agencies. The solutions to these problems are complex but there is clearly a need for all relevant disciplines to work together more closely in the planning and provision of child mental health services at both an individual case and strategic development level.

\section{References}

Church, H., Hedderman, E. \& SMrth, J. M. (1993) The practice of child psychiatry - what do other junior doctors know? Poster presentation at Annual Meeting of Royal College of Psychiatrists, Child Psychiatry Section. Warwick Untversity, September 1993.

DOVER, S. J.: LEAHY, A. \& Foreman, D. (1994) Parental psychiatric disorder: clinical prevalence and effects on default from treatment. Child: Care, Health and Development, 20, 137-143.

KURTZ. Z., THORNES, R. \& WOLKIND, S. (1994) Services for the Mental Health of Children and Young People in England-A National Review. London: South Thames RHA.

LEARMonth, M., PRYCE-Jones, M. \& TOTterdell, B. J. (1990) Using customer satisfaction surveys to improve service quality. Health Services Management. 86. 273-274. 
MARKANTONAkis, A \& MATHN, J. (1990) An evaluation of general practitioners' knowledge and satisfaction of a local child and family psychiatric service. Psychiatric Bullettr, 14, 328-329.

NHS Healty AdVISORY Service (1995) Together We Stand. London: HMSO.

OKE, S. \& MAYER, R. (1991) Referrals to child psychiatry - a survey of staff attitudes. Archives of Disease in Childhood, 68, 862-865.
Thompson, A. \& PuACE, M. (1995) What influences general practitioners' use of child psychiatric services? Psychiatric Bullettr, 19. 10-12.

S. J. Dover, Senior Clinical Lecturer in Child and Adolescent Psychiatry, Keele University, School of Postgraduate Medicine, Thornburrow Drive, Hartshill, Stoke-on-Trent, Staffs ST4 7QB 